\title{
An Analysis of Determinants of Agriculture Trade Intensities of South Asia
}

\author{
Pradeepa Dembatapitiya ${ }^{1}$
}

\begin{abstract}
South Asia is considered as the least integrated region in the world despite many attempts made to liberalize movement of goods and services within the region. Intra-regional total trade and agricultural trade among South Asian countries are about 4\% and $8 \%$ respectively. The objectives of this study are to document the extent of intra-regional trade of South Asia using trade intensities and to evaluate the determinants of the same using gravity models. Three equations were estimated taking exporter GDP, importer GDP, exporter population, importer population, distance, WTO membership, regional and bilateral trade agreements, common language, common colony and diversification index as the independent variables for the year 2010. The first model used total-trade intensities as the dependent variable and covered 2490 country pairs. The second and third models were sub-samples covering total trade and agricultural trade respectively in South Asia. The results show that higher agriculture trade exchanges exist between Pakistan-Afghanistan and Nepal-Bhutan. Total trade intensities are higher for Afghanistan-Pakistan and Afghanistan-India. The estimation results of gravity models indicate that exporter GDP, importer population, distance and colonial ties are significant determinants of trade intensity in all three models. Even though WTO membership and regional trade agreements are key determinants of both world and South Asian total trade, they do not significantly influence agriculture trade. Bilateral trade agreements have strong influence in strengthening trade relationships in agriculture trade intensities in South Asian region. Export market diversification is a key determinant of trade intensities.
\end{abstract}

\section{Introduction}

South Asia is considered as the least integrated region in the world despite many attempts made to liberalize movement of goods and services within the region. Intra-regional total trade and agricultural trade among South Asian countries constitute about $4 \%$ and $8 \%$ respectively. It is evident that agricultural exports of South Asia are confined to primary agriculture products to limited number of countries and trade relationships are prevalent

1 Graduate student, Department of Agricultural Economics and Business Management, Faculty of Agriculture, University of Peradeniya, Sri Lanka. 
among few traditional trading partners outside the region. According to Rosa and Govindan (1997), there are still room for gains in agriculture trade of South Asia through integrations of fast growing economies in the region and more trade liberalization within the region. Strengthening of agriculture trade linkages among countries in the region will be an important area in future trade policy discussions and negotiations in the region.

Forbes and Chinn (2004), who addressed importance of trade linkages across countries, suggested that trade linkages are highly significant determinants of a country's economic situation in terms of income effect. According to Zhang and Witteloostuijn (2004) the value of bilateral trade volume does not imply the strength and importance of trade relationships between two countries. They used trade intensity index to measure trade linkages and indicated that trade intensity index normalize many factors that affect trade flow such as openness, exchange rate, price level. These country specific factors have an equal impact on bilateral trade flow with its all trading partners but not the trade structure with the partners, and hence it captures the relative importance of trade relationships between two countries explicitly. The trade intensity index with a value greater than one indicates higher bilateral trade than it can be expected on the basis of country's share in world trade. The changes in the trade intensity index over time reflect the changes in trade prospects of two countries. The increasing value of trade intensity overtime implies the further trade integration of two nations and can be used to depict prospects for regional economic integration (Batra, 2007).

Past studies on determinants of trade intensity mainly focused on the relationship between distance and trade. Distance is a strong determinant of trade flow that geographic proximity tends to promote relatively more trade between two nations (Ng and Yeat, 2003). According to Srivastava and Green (1986), distance, GDP of exporting country and population of the importing country are significant determinants of the trade intensity between two countries. Their findings revealed that market power is exerted by large economies and, nations with large economies have diversified large number of firms and exports across the importing nations. Carney (1973) analyzing agricultural trade intensity among United State and European community argued that, implementation of discriminatory commercial policies were influenced trade intensity between two nations. Reza (1982) revealed that Bangladesh has extremely low trade intensities with South Asian member countries. Shin (2008) also examined how export and import intensities have evolved in Europe and East Asia. Zang and Witteloostuijn (2004) explained that the differences for export vis-à-vis import intensities and the political determinants of trade intensities are as important as economic explanations. The findings of Bano et al. (2013) on the potentials of trade development 
between ASEAN and New Zealand using trade intensity indices observed the intensified trade over the years and revealed the scope for further deepening of trade relationship, especially with countries geographically closer to New Zealand and need for bilateral trade agreements for strong trade relationship between two nations.

Despite the abundant literature focused on trade intensities, there is dearth of studies on agriculture trade intensities in the South Asian region. Irrespective of several attempts for regional and bilateral trade agreements between South Asian countries such as South Asian Preferential Trade Agreement (SAPTA), Indo-Sri Lanka Free Trade Agreement, Sri LankaPakistan bilateral trade agreement, agricultural trade among the region remains low. The issue of why the region is below optimal in gains through regional trade and what factors hinder countries in capitalizing on intra regional trade opportunities remains to be investigated. This study attempts to fill this gap partly by comparative trade flow analysis of the South Asia region and the world with particular emphasis on agricultural trade flows within South Asia.

Accordingly, the study has two objectives. Firstly, the study investigates how intense is the total trade and agriculture trade within South Asia. Secondly, this study evaluates the factors that determine the agricultural trade intensity between two nations using gravity models.

The paper is organized as follows. First, this paper discuss the nature of agriculture trade flow in South Asia by emphasizing its major trading partners, main export commodities and concentration of export market. The following sections present the analytical framework. The results of trade intensity calculations and gravity model estimations are presented next. The paper ends with conclusions.

\section{Agriculture Trade in South Asian Region}

\section{Openness of South Asian Countries}

Over the past few decades, most countries in the world opened up their economies have adopted more outward looking trade policies to increase their country share in world export market. Openness of a country explains how far a particular country interacts with other nations in trade. Table 1 shows the openness indices for South Asian countries over the period 20082013. 
62

Table 1: $\quad$ Openness indices for South Asian member countries

\begin{tabular}{lccccc}
\hline & $\mathbf{2 0 0 8}$ & $\mathbf{2 0 0 9}$ & $\mathbf{2 0 1 0}$ & $\mathbf{2 0 1 1}$ & $\mathbf{2 0 1 2}$ \\
\hline World & 0.52 & 0.42 & 0.47 & 0.51 & 0.50 \\
South Asia & 0.41 & 0.33 & 0.34 & 0.41 & 0.41 \\
Afghanistan & 0.35 & 0.30 & 0.35 & 0.38 & 0.32 \\
Bangladesh & 0.45 & 0.40 & 0.47 & 0.52 & 0.49 \\
Bhutan & 0.85 & 0.81 & 0.80 & 0.82 & 0.82 \\
India & 0.41 & 0.32 & 0.33 & 0.41 & 0.42 \\
Maldives & 0.80 & 0.53 & 0.55 & 0.69 & 0.77 \\
Nepal & 0.00 & 0.36 & 0.37 & 0.36 & 0.30 \\
Pakistan & 0.37 & 0.29 & 0.33 & 0.32 & 0.30 \\
Sri Lanka & 0.54 & 0.39 & 0.42 & 0.50 & 0.46 \\
\hline
\end{tabular}

Source: Author calculations using World Bank data base

Table 1 clearly indicates that openness of South Asian region is relatively lower compared to the world average and it remains unchanged during past few years. During 2012, openness index for South Asia and World are 0.5 and 0.41 respectively. However, on average Bhutan and Maldives are relatively more open economies in the region and greater than the world average.

\section{Position of South Asia in the World Economy}

Figure 1 depicts the relative position of South Asia in terms of world total product and agricultural product exports. Accordingly South Asia is the smallest region when total exports are concerned. The smallest agriculture exports share is recorded by the Middle-East followed by South Asia. The highest contribution of Middle-East for total trade is due to petroleum oil. 
Figure 1: $\quad$ Total exports shares and agricultural exports shares in different geographical regions in the world

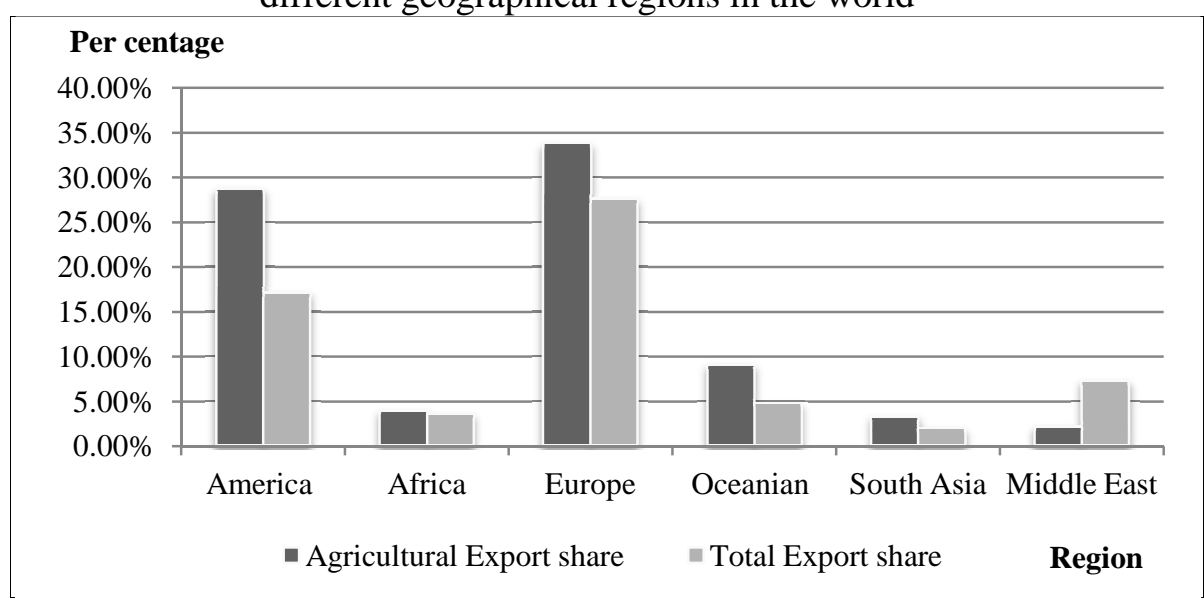

Source: COMTRADE data (Export value based calculations for 2012)

Within South Asia, export shares of both total product and agricultural product trade shows rise and fall pattern during past decade. Figure 2 depicts the intra-regional export shares of South Asia during past decade.

Figure 2: $\quad$ Intra-regional export shares of South Asia

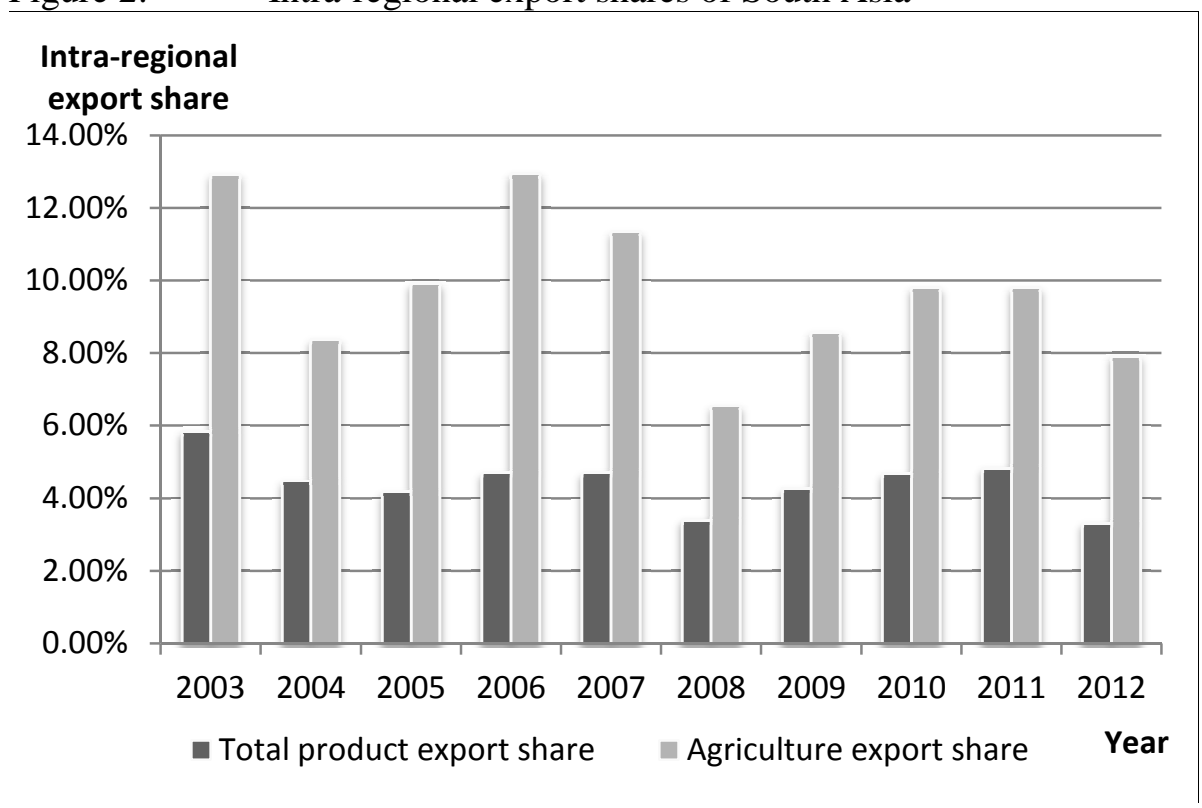

Source: COMTRADE data 
South Asia mainly exports its agricultural products to high income OECD and non-OECD countries and its exports to both upper and lower middle income countries remains low. Cereals such as rice, wheat, maize, sorghum and millet etc are the main exported agricultural commodities from South Asian and those products are primarily exported to Indonesia, Malaysia, Senegal, China and United Kingdom (COMTRADE data). Table 2 shows top five agricultural export commodities of South Asia.

Table 2: Top five agricultural export commodities of South Asia $^{2}$

\begin{tabular}{lrrrr}
\hline Product & $\mathbf{2 0 0 8}$ & $\mathbf{2 0 0 9}$ & $\mathbf{2 0 1 0}$ & $\mathbf{2 0 1 1}$ \\
\hline Total Agriculture exports & $\mathbf{2 0 , 9 7 1 , 7 7 7}$ & $\mathbf{2 6 , 6 2 4 , 5 1 6}$ & $\mathbf{3 9 , 2 4 4 , 9 1 8}$ & $\mathbf{4 6 , 0 9 7 , 1 0 8}$ \\
& $\mathbf{( 1 0 0 . 0 0 \% )}$ & $\mathbf{( 1 0 0 . 0 0 \% )}$ & $\mathbf{( 1 0 0 . 0 0 \% )}$ & $\mathbf{( 1 0 0 . 0 0 \% )}$ \\
\hline Cereals & $4,836,984$ & $5,217,780$ & $8,194,737$ & $10,813,354$ \\
& $(23.06 \%)$ & $(19.60 \%)$ & $(20.88 \%)$ & $(23.46 \%)$ \\
Lac, gums, resins, vegetable saps and & 415,349 & 730,952 & $2,397,597$ & $6,736,237$ \\
extracts & $(1.98 \%)$ & $(2.75 \%)$ & $(6.11 \%)$ & $(14.61 \%)$ \\
Coffee, tea, mate' and spices & $2,909,720$ & $3,703,792$ & $4,804,612$ & $4,506,046$ \\
& $(13.87 \%)$ & $(13.91 \%)$ & $(12.24 \%)$ & $(9.78 \%)$ \\
Fish, crustaceans, molluscs, aquatic & $2,339,635$ & $3,192,562$ & $4,411,547$ & $4,331,279$ \\
invertebrates & $(11.16 \%)$ & $(11.99 \%)$ & $(11.24 \%)$ & $(9.40 \%)$ \\
Meat and edible meat offal & $1,262,422$ & $1,903,881$ & $2,860,058$ & $3,359,613$ \\
& $(6.02 \%)$ & $(7.15 \%)$ & $(7.29 \%)$ & $(7.29 \%)$ \\
\hline
\end{tabular}

Source: COMTRADE data (US \$ Thousands)

South Asia shows regional outward orientation for both its agricultural exports and imports. South Asian region accounts about $8 \%$ of its intra-regional agriculture exports during 2012. South Asian intra-regional agriculture imports remains at about $6 \%$ during same year whereas $94 \%$ of its agricultural imports come from outside the region (COMTRADE data). Table 3 and 4 depict top ten agriculture export destinations and import sources of South Asia respectively. Accordingly about $91 \%$ of its agricultural trade is with outside the region. It is notable that India and Pakistan are among the top ten import sources of the region as South Asia heavily depends on cereal imports from India and milling product imports from Pakistan.

\footnotetext{
${ }^{2}$ Percentage in parenthesis indicate export share to total agriculture exports from South Asia.
} 
65

Table 3: $\quad$ Top ten agriculture export destinations in South Asia

\begin{tabular}{lrrrrr}
\hline Importers & $\mathbf{2 0 0 8}$ & $\mathbf{2 0 0 9}$ & $\mathbf{2 0 1 0}$ & $\mathbf{2 0 1 1}$ & $\mathbf{2 0 1 2}$ \\
\hline United States of & $1,944,035$ & $1,629,968$ & $2,106,611$ & $3,487,284$ & $6,276,446$ \\
America & 708,209 & 545,922 & 925,183 & $1,177,858$ & $1,495,077$ \\
China & $1,226,414$ & 872,839 & $1,109,713$ & $1,604,203$ & $1,370,042$ \\
Japan & $1,086,318$ & 829,949 & 934,078 & $1,258,135$ & $1,348,096$ \\
Malaysia & 563,748 & 397,866 & 548,085 & $1,169,887$ & $1,223,550$ \\
Indonesia & 787,106 & 754,693 & 888,152 & $1,172,743$ & $1,105,753$ \\
Germany & $1,014,910$ & 883,997 & 931,229 & $1,090,661$ & $1,081,104$ \\
United Kingdom & 665,265 & 655,428 & 804,778 & $1,043,101$ & 975,232 \\
Russian Federation & 72,572 & 116,771 & 190,291 & 288,680 & 959,008 \\
Nigeria & 706,216 & 499,532 & 543,417 & 798,004 & 764,353 \\
France & & & &
\end{tabular}

Source: COMTRADE data (US\$ Thousands)

Table 4: $\quad$ Top ten agriculture import sources in South Asia

\begin{tabular}{lrrrrr}
\hline Exporters & $\mathbf{2 0 0 8}$ & $\mathbf{2 0 0 9}$ & $\mathbf{2 0 1 0}$ & $\mathbf{2 0 1 1}$ & $\mathbf{2 0 1 2}$ \\
\hline Indonesia & $5,608,808$ & $4,510,290$ & $5,674,616$ & $7,161,676$ & $7,039,143$ \\
Malaysia & $2,230,421$ & $2,188,089$ & $3,119,911$ & $4,217,423$ & $4,291,624$ \\
India & $2,201,726$ & $1,394,364$ & $2,304,099$ & $2,584,995$ & $2,621,696$ \\
Ghana & 133,055 & 26,618 & 21,433 & 487,464 & $1,825,647$ \\
Brazil & 637,638 & $2,492,043$ & $1,942,491$ & $1,253,880$ & $1,704,358$ \\
Argentina & $1,011,755$ & 794,522 & $1,446,611$ & $1,507,964$ & $1,477,277$ \\
Australia & 488,640 & 693,236 & $1,143,792$ & 994,698 & $1,445,160$ \\
Pakistan & 697,274 & 572,668 & 732,783 & $1,604,899$ & $1,339,046$ \\
Canada & $1,282,734$ & $1,463,301$ & $1,638,050$ & $1,925,247$ & $1,323,286$ \\
Ukraine & 236,689 & 782,864 & 682,169 & $1,001,919$ & $1,268,943$ \\
\hline Source: COMTRADE & & & & & \\
\hline
\end{tabular}

Source: COMTRADE data (US \$ Thousands)

Table 5 shows the agriculture exports shares of South Asian countries as a percentage of total agriculture exports to the region. 
Table 5: Agriculture exports shares of South Asian Countries compared to each country's total agriculture exports to South Asia region $(\%)$

\begin{tabular}{lccccccccc}
\hline & Afghanistan & Bangladesh & Bhutan & India & Maldives & Nepal & Pakistan & Sri Lanka & Total \\
\hline Afghanistan $^{3}$ & - & 0.00 & 0.00 & 75.92 & 0.00 & 00 & 24.01 & 0.07 & 100 \\
Bangladesh $^{4}$ & 0.07 & - & 1.67 & 87.28 & 0.35 & 1.51 & 8.33 & 0.86 & 100 \\
Bhutan & 0.00 & 12.04 & - & 87.81 & 0.00 & 0.15 & 0.00 & 0.00 & 100 \\
India & 2.51 & 42.3 & 0.53 & - & 1.71 & 10.9 & 23.21 & 18.9 & 100 \\
Maldives & 0.00 & 0.00 & 0.00 & 0.03 & - & 0.00 & 0.00 & 99.97 & 100 \\
Nepal & 0.00 & 25.89 & 0.19 & 73.36 & 0.01 & - & 0.19 & 0.37 & 100 \\
Pakistan & 75.84 & 9.12 & 0.00 & 6.13 & 0.34 & 0.02 & - & 8.56 & 100 \\
Sri Lanka & 0.03 & 1.30 & 0.001 & 70.52 & 11.24 & 0.10 & 16.80 & - & 100 \\
\hline
\end{tabular}

Source: Calculations based on COMTRADE data (Average values for 2008 - 2012)

India, Sri Lanka and Bangladesh are only South Asian members which have agriculture trade with each country in the region. AfghanistanIndia, Bangladesh-India, Bhutan-India, Sri Lanka-India, Maldives-Sri Lanka, Nepal-India and Pakistan-Afghanistan show a higher agriculture trade within the region in terms of export shares. India plays an important role in agriculture trade in South Asia. Agriculture export share of India is highest with Bangladesh and it is $42.3 \%$. About $87.28 \%$ of Bangladesh agriculture exports supply to India too. Bhutan exports agriculture commodities to Bangladesh, India and Nepal only and $87.8 \%$ of agriculture exports of Bhutan supply to India. Agriculture exports of Sri Lanka are also highest with India and its exports share is $70.5 \%$. It is notable that Maldives supplies $99.9 \%$ of its agriculture exports to Sri Lanka and rest to India. Nepal exports its agriculture products to each South Asian country except Afghanistan and that is highest with India. About $75.8 \%$ of agriculture exports of Pakistan supply to Afghanistan. Afghanistan exports its agriculture products only to India, Pakistan and Sri Lanka within South Asian region.

\section{Trade potential within South Asia}

Trade complementary indices provide insight for potentials of trade between two countries. It explains how far one country's exports match with the imports of another country and is considered a good indicator to find

\footnotetext{
${ }^{3}$ Calculations based on mirror data.

${ }^{4}$ Calculations based on mirror data as COMTRADE data shows direct data only up to 2007.
} 
natural trading partners in the region. Table 6 shows the trade complementary indices for South Asian countries.

Table 6: $\quad$ Trade complementarity indices for South Asian countries ${ }^{5}$

\begin{tabular}{|c|c|c|c|c|c|c|c|c|}
\hline & Afghanistan & Bangladesh & Bhutan & India & Maldives & Nepal & Pakistan & $\begin{array}{c}\text { Sri } \\
\text { Lanka }\end{array}$ \\
\hline Afghanistan $^{6}$ & - & 49.37 & 43.96 & 42.97 & 44.54 & 47.71 & 50.39 & 46.88 \\
\hline Bangladesh $^{7}$ & 29.09 & _ & 28.51 & 28.03 & 31.39 & 42.47 & 29.38 & 30.08 \\
\hline Bhutan & 68.69 & 49.14 & - & 46.69 & 67.47 & 53.26 & 47.83 & 50.49 \\
\hline India & 44.59 & $34.82 \quad 3$ & 8.24 & - & 41.70 & 40.78 & 34.21 & 38.20 \\
\hline Maldives & 52.66 & 68.53 & 92.49 & 62.78 & - & 65.59 & 52.52 & 46.72 \\
\hline Nepal & 41.64 & 39.10 & 73.57 & 43.99 & 40.55 & - & 42.74 & 42.06 \\
\hline Pakistan & 35.69 & 31.62 & 53.87 & 28.70 & 34.41 & 29.51 & - & 27.72 \\
\hline Sri Lanka & 27.21 & 21.63 & 57.40 & 30.13 & 19.50 & 25.53 & 25.56 & - \\
\hline
\end{tabular}

Source: WITS database (2011)

Pakistan is potential trade partner of Afghanistan among other trade partners in South Asia. Bangladesh does not have potential trading partners within the region where it shows less than 50 values for complementarity indices with all regional member countries. Afghanistan, Sri Lanka, Maldives and Nepal are the better trading partners of Bhutan as exports of Bhutan match with the import requirement of those countries at the level of more than 50\%. It is notable that trade complementary indices of India are not higher compared to

\footnotetext{
${ }^{5}$ Trade complementarity index measures how far exports of one country overlap with the imports of another country and it is calculated according to the following formula (United Nations Economic and Social Commission for Asia and the Pacific, 2009).

$$
\mathrm{TC}=100\left[1-\sum_{k}\left(M_{k}^{l}-x_{h}^{j}\right) / 2\right.
$$

Where, $\mathrm{M}_{\mathrm{k}}{ }^{\mathrm{i}}$ is sector k's share in i'th country total imports from the world and $\mathrm{X}_{\mathrm{k}}{ }^{\mathrm{j}}$ is sector k's share in $\mathrm{j}$ 'th country total exports to the world.

The index is zero when no goods are exported by one country or imported by another. It is 1 (100 per cent) when export share of one country exactly match with the import share on another. In this study, if index is greater than 0.5 (50 per cent) those country pairs are identified as potential/ fair natural trading partners. If it more close to 1 (100 per cent) those country pairs are identified as best natural trading partners.

${ }^{6}$ Based on mirror data

${ }^{7}$ Based on mirror data
} 
other countries. It highlights that India seeks its better trading partners outside the region. All South Asian countries are potential trading partners of Maldives and it is less with Sri Lanka in contrast to other countries in the region. Maldives and Bhutan are the best trading partners in South Asia as it records the highest complementary index in the region. Nepal and Bhutan are natural trading partners in the region where their respective imports and exports match in $73.5 \%$. Bhutan is also a good trading partner of both Pakistan and Sri Lanka where their relevant exports and imports are matched in $53.8 \%$ and $57.4 \%$ respectively.

\section{Export Diversification in South Asia}

Table 7 shows the Herfindhal indices for agriculture commodity exports from South Asian countries. Herfindhal index is the simplest method to measure the export market diversification. High value of Herfindhal index reflects more exports are concentrated into few sectors in the economy. Accordingly, South Asia shows relatively monopolistic nature in agricultural commodity exports except India. South Asian agriculture exports are concentrated into few commodities and this situation is significant in Maldives where more than $80 \%$ of its agricultural exports consist with fish and crustacean products.

Table 7: Herfindhal index for agricultural trade in South Asian member countries

\begin{tabular}{llllll}
\hline Country & $\mathbf{2 0 0 8}$ & $\mathbf{2 0 0 9}$ & $\mathbf{2 0 1 0}$ & $\mathbf{2 0 1 1}$ & $\mathbf{2 0 1 2}$ \\
\hline Afghanistan & 0.75 & 0.51 & 0.36 & 0.40 & 0.35 \\
Bangladesh & 0.60 & 0.60 & 0.49 & 0.50 & 0.48 \\
Bhutan & 0.89 & 0.25 & 0.21 & 0.18 & 0.33 \\
India & 0.10 & 0.10 & 0.08 & 0.09 & 0.12 \\
Maldives & 0.84 & 0.79 & 0.83 & 0.83 & 0.91 \\
Nepal & $\mathrm{N} / \mathrm{A}$ & 0.16 & 0.17 & 0.15 & 0.25 \\
Pakistan & 0.42 & 0.36 & 0.37 & 0.29 & 0.21 \\
Sri Lanka & 0.46 & 0.47 & 0.48 & 0.43 & 0.45 \\
\hline
\end{tabular}

Source: Author calculations based on COMTRADE data 
In summary, South Asia has lower level of agriculture trade and those exports are concentrated into few sectors of the economy. Its major export destinations and import sources are located outside the region. Thus it can be concluded that intra regional agriculture trade is at lower level in contrast to other major geographical regions in the world. The potentials for intra regional trade is high in the country pairs of Maldives-Bhutan, Nepal-Bhutan in South Asia according to the trade complementary indices.

\section{Analytical Framework}

\section{Calculation of Agriculture Trade Intensity Indices for South Asian Countries}

Trade Intensity Index is measured as the ratio of the shares of country's exports going to partner country over the share of world export going to the same partner (United Nations Economic and Social Commission for Asia and the Pacific, 2009). Agriculture trade intensities for South Asian countries are calculated according to the following formula using UNCOMTRADE data.

$$
\operatorname{TI}_{\mathrm{i}}^{\mathrm{j}}=\frac{\mathrm{X}_{\mathrm{i}}^{\mathrm{j}} / \mathrm{X}_{\mathrm{i}}}{\mathrm{X}_{\mathrm{w}}^{\mathrm{j}} / \mathrm{X}_{\mathrm{w}}}
$$

Where,

$\begin{array}{lll}\mathrm{TI}_{\mathrm{j}}^{\mathrm{j}} & = & \text { Trade intensity between } \mathrm{i}^{\text {th }} \text { and } \mathrm{j}^{\text {th }} \text { country } \\ \mathrm{X}_{\mathrm{i}}^{\mathrm{j}} & = & \text { Agriculture exports from } \mathrm{i}^{\text {th }} \text { country to } \mathrm{j}^{\text {th }} \text { country } \\ \mathrm{X}_{\mathrm{i}} & = & \text { Total agricultural exports from } \mathrm{i}^{\text {th }} \text { country } \\ \mathrm{X}_{\mathrm{w}}{ }^{\mathrm{j}} & = & \text { Agriculture exports from world to } \mathrm{j}^{\text {th }} \text { country } \\ \mathrm{X}_{\mathrm{w}} & = & \text { World total agriculture exports }\end{array}$

\section{Gravity Model Estimation}

Following Srivastava and Green (1986) and Zhang and Witteloostuijn (2004) the factors that influence on the intensity in bilateral trade between two countries were estimated using gravity model by setting $\log$ of trade intensity as the response variable.

Size of the economies, population, distance between two countries, WTO membership, presence of bilateral and regional trade agreements, export diversification index and some similar geographical characteristics such as common colony, common language are used as the independent variables. The algebraic specification of the model used for the econometric estimation is given below. 

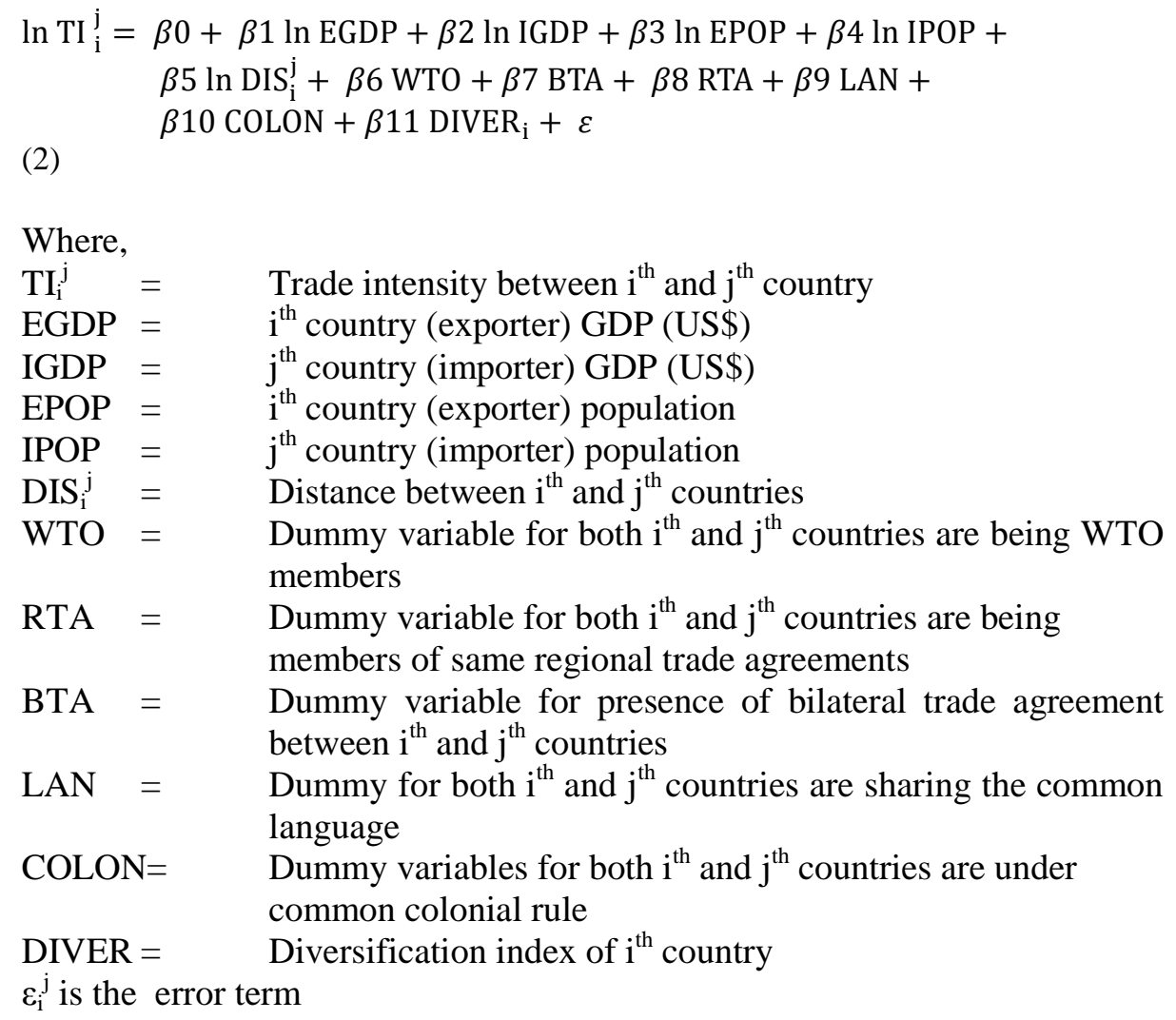

Three regression models are estimated separately for world total trade, South Asian total trade and for South Asian agriculture trade. To address the heteroscedasticity issue, robust standard error method is used for correction. Unobservable multilateral resistance of gravity data is corrected including importer fixed effects in the model. As diversification index is collinear with the exporting country, exporter fixed effects are not included in the model.

Cross sectional gravity data of this study is consisted with 42 exporting countries across the world and 2490 of country pairs which show the respective trade intensities of their bilateral trade during 2010. Information on country's GDP and the population are obtained from World Bank database and data for dummy variables such as common language, Common colony were gathered from the database of the Institute for Research on the International Economy. Trade intensity index and Diversification index are obtained from World Integrated Trade Solution (WITS) database under HS 2007 nomenclature and the trade intensity indices that are not available in WITS database are calculated using COMTRADE data base. 


\section{Results and Discussion}

\section{Agriculture Trade Intensities in South Asian Region}

Table 8 shows trade intensity indices for South Asian member countries for their total product traded during 2011.

Table 8: $\quad$ Trade intensity indices for total trade among South Asian member countries

\begin{tabular}{|c|c|c|c|c|c|c|c|c|}
\hline & Afghanistan & Bangladesh & Bhutan & India & Maldives & Nepal & Pakistan & $\begin{array}{c}\text { Sri } \\
\text { Lanka }\end{array}$ \\
\hline Afghanistan $^{8}$ & - & 00 & 00 & 919 & 00 & 00 & 16,214 & 1.36 \\
\hline Bangladesh $^{9}$ & N/A & - & 226 & 81.5 & 42.7 & 213 & 123 & 80.5 \\
\hline Bhutan & 00 & 32 & - & 04 & 00 & 01 & 00 & 00 \\
\hline India & 2.08 & 6.2 & 35 & - & 6.2 & 03 & 3.08 & 15 \\
\hline Maldives & 00 & 00 & 00 & 01 & - & 00 & 00 & 120 \\
\hline Nepal & 0.16 & 16 & 17 & 03 & 0.38 & - & 1.62 & 0.24 \\
\hline Pakistan & 130 & 20 & 00 & 00 & 3.39 & 00 & - & 14 \\
\hline Sri Lanka & 0.38 & 2.5 & 0.5 & 02 & 86 & 0.2 & 4.17 & - \\
\hline
\end{tabular}

Source: WITS database and COMTRADE database ${ }^{10}(2011)$

The highest trade intensity index for total trade recorded between Afghanistan and Pakistan which explains that they are the strongest trade partners within South Asia. Afghanistan exports carpets and other textile floor coverings, leather and edible fruits to Pakistan. Afghanistan and India recorded the next most powerful trade linkages within South Asian region. Bangladesh shows highly strong trade relationships with Bhutan, Nepal and Pakistan. Bhutan shows strong bilateral trade relationship with Bangladesh, India and Nepal and trade intensity indices reported for these countries are more than unity. Bhutan records the highest trade intensity index with Bangladesh among other trading partners in the region. India has trade intensities above unity with all South Asian countries and has strong trade partnership with all member countries in the region. It is notable that Sri Lanka and Maldives are strong trade partners reporting very high trade intensity index between two countries among their other trade partners.

\footnotetext{
${ }^{8}$ Based on mirror data.

${ }^{9}$ Based on mirror data.

${ }^{10}$ Trade intensity indices of Afghanistan, Bangladesh and Bhutan are calculated by the author using COMTRADE database.
} 
However, Sri Lanka has weak trade relationships with Bhutan, Nepal and Afghanistan, which is below the regional averages. Nepal has well-built trade relationships with Bhutan, Bangladesh, India and Pakistan while it is weak with Maldives and Sri Lanka. The strongest trade relationship of Nepal within the region prevails with Bhutan having the highest trade intensity index in South Asian region. Pakistan shows strong trade relationships with Afghanistan, Bangladesh, Maldives and Sri Lanka while its trade is nonexistent with other South Asian member countries.

Table 9 presents the agricultural trade intensities in South Asian region. It is notable that agriculture trade intensities in the region are higher than its total product trade intensities.

Table 9: Agricultural trade intensity indices among South Asian member countries

\begin{tabular}{lcccccccc}
\hline & Afghanistan & Bangladesh & Bhutan & India & Maldives & Nepal & Pakistan & $\begin{array}{c}\text { Sri } \\
\text { Lanka }\end{array}$ \\
\hline $\begin{array}{l}\text { Afghanistan } \\
\text { 11 }\end{array}$ & - & 00 & 00 & 4,466 & 00 & 00 & 4,293 & 0.68 \\
$\begin{array}{l}\text { Bangladesh } \\
\text { 12 }\end{array}$ & N/A & - & 2,537 & 1,414 & 185 & 432 & 166 & 112 \\
Bhutan & 00 & 8,065 & - & 5,384 & 00 & 808 & 00 & 00 \\
India & 140 & 701 & 3,622 & - & 828 & 3,064 & 487 & 1,231 \\
Maldives & 00 & 00 & 00 & 1.60 & - & 1.54 & 00 & 6,770 \\
Nepal & 00 & 2,847 & 8,878 & 6,913 & 28.20 & - & 50.21 & 4.12 \\
Pakistan & 12,476 & 1,220 & 00 & 108 & 336 & 20.43 & - & 1,479 \\
Sri Lanka & 00 & 18 & 9.3 & 537 & 6,202 & 38.12 & 276 & - \\
\hline
\end{tabular}

Source: WITS database and COMTRADE database ${ }^{13}(2011)$

Similar to total trade relationships reported, Afghanistan's agricultural trade relationships are highest with India and Pakistan. But it is less intense with Sri Lanka. Bangladesh also shows strong agricultural trade relationships with Bhutan, India, Maldives, Nepal, Pakistan and Sri Lanka. Bangladesh shows the highest agricultural trade relationship with Bhutan. Bhutan's agricultural trade intensities reported are more than unity for Bangladesh, India and Nepal showing strong trade relationships for agricultural goods. Bhutan's agriculture trade intensity index is highest with

\footnotetext{
${ }^{11}$ Based on mirror data.

${ }^{12}$ Based on mirror data.

13 Trade intensity indices of Afghanistan, Bangladesh and Bhutan are calculated by author using COMTRADE database.
} 
Bangladesh. Again India has strong agricultural trade relationships with every South Asian country. Similar to trade intensity indices for total trade, Sri Lanka and Maldives reported the highest agriculture trade intensity index among trading partners of Maldives within the region. Sri Lanka exports edible vegetables and certain roots and tubers to Maldives and Sri Lanka highly dependent on Maldives for importation of fish products. Nepal has intense agriculture trade exchange with every South Asian country except Afghanistan where trade with Afghanistan is nonexistent. The strongest relationship of Nepal reports with Bhutan where live animals, meat and meat products, fish and dairy products are the main exports from Nepal to Bhutan. Pakistan has strong agriculture trade relations with each South Asian country except Bhutan. Its agriculture trade relationship is highest with Afghanistan which records the highest agriculture trade intensity index in South Asia. Milling products, animal fat, vegetable oil, cereals, edible fruits and vegetables are the main agricultural exports from Pakistan to Afghanistan.

It is notable that India is the only country having strong agriculture trade relationship with every South Asian member country. In addition Bhutan-Bangladesh, Sri Lanka-Maldives, Nepal-Bhutan and Nepal-India are the country pairs in South Asian region having strong trade relationships for agricultural goods.

According to trade complimentary indices, Maldives and Bhutan are better natural trading partners in South Asia where 92.4\% of Maldives exports overlap with the import demand of Bhutan. However, it records zero trade intensity index between two countries as trade between two countries is nonexistent. Similarly, Bhutan-Afghanistan, Bhutan-Maldives, MaldivesBangladesh and Pakistan-Bhutan are also potential trading partners' records with zero trade intensity indices. Thus there is a room for further trade policy interventions and trade negotiations between South Asian member countries to capitalize on the potential agricultural trade opportunities.

\section{Determinants of Trade Intensity: Results of Gravity Estimation}

Given the F-statistics for overall significance of the models, all three models are significant at 0.001 probability level. The R-squared values for the models of world total trade, South Asia total trade and South Asia agriculture trade are $38 \%, 41 \%$ and $54 \%$ respectively. Table 10 shows the descriptive statistics of the variables used in three gravity specifications.

Out of 2490 country pairs in econometric data of world total trade model, $17.08 \%$ represents South Asia, 10\% share common language and 3.5 $\%$ have strong colonial ties. About $80 \%$ of country pairs represent WTO 
members, $8.36 \%$ have bilateral trade agreements and $19.53 \%$ are members in regional trade agreements.

South Asia total trade model is a sub sample of world total trade data excluding non-South Asian country pairs. It represents trade with partner countries in both within and outside the region. South Asia agriculture trade model also include trading partners in both within and outside the region.

Table 10: Descriptive statistics of econometric data used in gravity specification

\begin{tabular}{|c|c|c|c|c|c|c|c|}
\hline \multirow[t]{2}{*}{ Variable } & \multirow[t]{2}{*}{ Units } & \multicolumn{2}{|c|}{ World Total Trade } & \multicolumn{2}{|c|}{$\begin{array}{c}\text { South Asia Total } \\
\text { Trade }\end{array}$} & \multicolumn{2}{|c|}{$\begin{array}{c}\text { South Asia } \\
\text { Agriculture Trade }\end{array}$} \\
\hline & & Mean & S.D. & Mean & S,D. & Mean & S.D. \\
\hline $\begin{array}{l}\text { Exporter } \\
\text { GDP }\end{array}$ & $\begin{array}{l}\text { US\$ } \\
\text { Billions }\end{array}$ & 1350 & 2560 & 990 & 1970 & 600 & 760 \\
\hline $\begin{array}{l}\text { Importer } \\
\text { GDP }\end{array}$ & $\begin{array}{l}\text { US\$ } \\
\text { Billions }\end{array}$ & 900 & 2080 & 690 & 1670 & 1070 & 2300 \\
\hline $\begin{array}{l}\text { Exporter } \\
\text { Population }\end{array}$ & Millions & 120 & 282 & 261 & 438 & 436 & 533 \\
\hline $\begin{array}{l}\text { Importer } \\
\text { Population }\end{array}$ & Millions & 82 & 226 & 178 & 360 & 78 & 193 \\
\hline $\begin{array}{l}\text { Trade } \\
\text { Intensity index }\end{array}$ & & 2.00 & 18.72 & 1.85 & 11.89 & 89.41 & 156 \\
\hline $\begin{array}{l}\text { Diversification } \\
\text { Index }\end{array}$ & & 0.57 & 0.10 & 0.62 & 0.11 & 0.68 & 0.08 \\
\hline $\begin{array}{l}\text { Number of } \\
\text { observations }\end{array}$ & & & & & & & \\
\hline
\end{tabular}

About $11.5 \%$ of the country pairs in South Asia total trade model share common language, $2.1 \%$ have strong colonial ties while it is $12.7 \%$ and $2.0 \%$ respectively for South Asia agriculture data. About $89.8 \%$ of country pairs in South Asia total trade model are WTO members, $17.8 \%$ have bilateral trade agreements and 5.8\% are members in regional trade agreements. About $88.3 \%$ of country pairs in South Asia agriculture trade are WTO members and $9.5 \%$ of them have bilateral trade agreements within the region. Out of 189 country pairs in South Asia agriculture trade model $22.8 \%$ have concluded with regional trade agreements in South Asia.

Table 11 depicts the correlation coefficients of each gravity variables with trade intensity variable for all three econometric estimations. 
Table 11: Correlation coefficients for econometric variables

\begin{tabular}{lccc}
\hline & World total trade & $\begin{array}{c}\text { South Asian total } \\
\text { trade }\end{array}$ & $\begin{array}{c}\text { South Asian } \\
\text { agriculture trade }\end{array}$ \\
\hline Correlation coefficients & & & \\
with trade intensity & $0.099^{* * *}$ & $0.109^{* * *}$ & 0.003 \\
Exporter GDP & $0.197^{* * *}$ & $0.196^{* * *}$ & 0.054 \\
Importer GDP & $0.141^{* * *}$ & $0.172^{* *}$ & $0.222^{* *}$ \\
Exporter population & $0.090^{* * *}$ & $0.187^{* * *}$ & 0.002 \\
Importer population & $-0.509^{* * *}$ & $-0.228^{* * *}$ & $-0.218^{* *}$ \\
ln distance & $0.066^{* * *}$ & $0.105^{* *}$ & $-0.123^{*}$ \\
WTO & $0.176^{* * *}$ & $0.243^{* * *}$ & $0.266^{* * *}$ \\
BTA & $0.413^{* * *}$ & $0.340^{* * *}$ & $0.026^{* * *}$ \\
RTA & $0.177^{* * *}$ & $0.151^{* *}$ & 0.038 \\
Common language & $0.115^{* * *}$ & $0.097^{* *}$ & 0.105 \\
Common colony & -0.024 & 0.072 & -0.018 \\
Diversification index & & & \\
Correlation coefficient & & & $1.000^{* * * *}$ \\
with exporter GDP & $0.800^{* * * *}$ & $0.704^{* * *}$ & \\
Exporter population & & & \\
\hline
\end{tabular}

*** Significant at 0.001 probability level

** Significant at 0.05 probability level

* Significant at 0.1 probability level

Accordingly exporter GDP, importer GDP, importer population, common language and common colony have positive correlation in total product trade intensities and it is significant. But they are not significant with agriculture trade intensities in South Asia. Exporter population has positive and significant association with both total and agriculture trade intensities. Distance has negative and significant association with both total and agriculture trade intensities. Dummy variables for regional and bilateral trade agreements are positively associated with both total and agriculture trade intensities. WTO membership positively associates with total product trade intensities while it shows negative relationship with agriculture trade intensity. Diversification of exporter country has no significant association with either total product or agriculture trade intensities. Table 12 shows the econometric specifications of determinants of trade intensity in world trade, South Asia trade and South Asia agriculture trade. 
Table 12: $\quad$ Gravity model estimations for determinants of trade intensity $^{14}$

\begin{tabular}{|c|c|c|c|c|c|c|}
\hline & \multicolumn{2}{|c|}{ World Total Trade } & \multicolumn{2}{|c|}{ South Asia Total Trade } & \multicolumn{2}{|c|}{$\begin{array}{c}\text { South Asia Agriculture } \\
\text { Trade }\end{array}$} \\
\hline & Coefficient & S.D. & Coefficient & S.D. & Coefficient & S.D. \\
\hline Constant & 3.935 & 2.378 & 5.364 & 5.970 & -55.233 & 10.981 \\
\hline In Exporter GDP & $0.325 * * *$ & 0.061 & $0.688 * *$ & 0.216 & $2.285 * *$ & 0.786 \\
\hline In Importer GDP & $-0.690 * * *$ & 0.122 & $-0.773 * *$ & 0.287 & -0.749 & 0.455 \\
\hline $\begin{array}{l}\text { In Exporter } \\
\text { population }\end{array}$ & 0.007 & 0.323 & $0.354 * *$ & 0.171 & $-1.813 *$ & 0.648 \\
\hline $\begin{array}{l}\text { In Importer } \\
\text { population }\end{array}$ & $0.590 * * *$ & 0.77 & $0.423 *$ & 0.235 & $1.501 * * *$ & 0.359 \\
\hline In distance & $-1.173 * * *$ & 0.053 & $-1.363 * * *$ & 0.291 & $1.774 * *$ & 0.624 \\
\hline WTO & $1.718 * * *$ & 0.303 & $2.687 * * *$ & 0.751 & 1.915 & 1.555 \\
\hline BTA & $0.631 * * *$ & 0.099 & $0.800 * *$ & 0.371 & $1.510 * *$ & 0.472 \\
\hline RTA & $0.379 * * *$ & 0.094 & $1.126 * *$ & 0.471 & -0.639 & 0.895 \\
\hline Common language & $0.640 * * *$ & 0.135 & 0.512 & 0.429 & 0.599 & 0.977 \\
\hline Common colony & $0.675 * * *$ & 0.195 & $0.774 * *$ & 0.263 & $3.113 * *$ & 0.986 \\
\hline \multirow[t]{2}{*}{$\begin{array}{l}\text { Diversification } \\
\text { index }\end{array}$} & $3.289 * * *$ & 0.573 & $5.047 * *$ & 1.825 & $10.779 * *$ & 4.54 \\
\hline & \multicolumn{2}{|c|}{$\begin{array}{l}\mathrm{N}=2427 \\
\mathrm{R}^{2}=0.38\end{array}$} & \multicolumn{2}{|c|}{$\begin{aligned} \mathrm{N} & =416 \\
\mathrm{R}^{2} & =0.41\end{aligned}$} & \multicolumn{2}{|c|}{$\begin{aligned} \mathrm{N} & =188 \\
\mathrm{R}^{2} & =0.54\end{aligned}$} \\
\hline
\end{tabular}

*** Significant at 0.001 probability level

** Significant at 0.05 probability level

* Significant at 0.1 probability level

As per the results of econometric estimations Exporter GDP, importer population, distance and colonial ties have statistically significant effects on trade intensity in all three estimations having significant influence on trade intensity. Importer GDP is a determinant of trade intensity in both world and South Asian total trade but it does not have significant influence on agriculture trade intensity. Common language significantly influences on total trade intensity in the world but it is not a determinant for trade intensity in South Asia. Even though exporter GDP is not a determinant in trade intensity for total trade in world, it influences on South Asian trade intensities. Being WTO members, bilateral trade and regional trade agreements influences trade intensity in total trade of both world and South Asia, but only bilateral trade agreements have significant influence on trade intensity of agriculture products in the region. Export market diversification is important in both world and South Asian trade situations. Diversification index is a determinant

\footnotetext{
${ }^{14}$ The sample size of total product and agriculture product model are different due to limitations with data availability. Observations with zero trade intensity are automatically omitted in econometric estimations treating them as missing data.
} 
in both world and South Asia total product trade intensities and also in agriculture trade intensity in South Asian region.

Positive significant coefficients for exporter country GDP appeared in all three estimations indicate that for one per cent increase in the size of the exporter economy increases trade intensity by $0.32 \%, 0.68 \%$ and $2.28 \%$ in world total product, South Asia total product and South Asia agriculture products trade intensities respectively. The influences of exporter GDP on total product trade is higher in South Asia compared to the trade in the world and also it is greater in agriculture trade in contrast to total products trade in South Asia.

The coefficient for importer GDP is negative in sign and significant for two estimations, reducing trade intensity of total product $0.69 \%$ due to one per cent increase in importer GDP and $0.77 \%$ in South Asia trade intensity. It does not influence agriculture trade intensity. Thus, being a trading partner of large economies does not have any significant effect on the strength of trade linkages for agriculture products in South Asia.

Exporter population positively influences total product trade intensities of South Asian region while it influence is negative in agriculture commodity trade. One per cent increase in exporter population will increase the total product trade intensities in South Asia by $0.35 \%$ while it decreases agriculture trade intensity by $1.81 \%$. According to the correlation analysis between GDP and population of exporter country, GDP and population are positively correlated. When population of exporter country increases it eventually increases labour force in the country. It causes to increase in production of goods and services that increases country's GDP. Expansion of production leads more trade opportunities and increases exports leading to a positive sign in total trade intensity. But when it comes to agriculture trade, it shows a negative sign. While it is true that high population in exporter country led to high production and increased exports, the negative sign in agriculture trade suggests that though total trade increases, agriculture trade tend to decline. This can be due to labour force transition in agriculture sector to manufacturing or service sectors with GDP growth. Thus agriculture trade intensities could decline.

The coefficient of importer population is significant and positive in sign in all three estimations. For one per cent increase in importer population increases trade intensity in world total trade and South Asia total trade and South Asia agriculture trade by $0.59 \%, 0.42 \%$ and $1.5 \%$ respectively. Having trading partner with high population is beneficial for agriculture trade as population of importer country shows positive relationship with trade 
intensity. The correlation coefficient between two variables is 0.002 (Table 11).

Distance is a proxy for transport cost and its influence is significantly negative on total product trade where one per cent increases in distance decreases the total product trade intensities in world and South Asia by $1.17 \%$ and $1.36 \%$ respectively. In contrast, a positive sign with a coefficient of 1.77 is revealed for agricultural trade in the region indicating more agriculture trade relationships with outside the region. As clearly explained in table 3, South Asia has its top ten agriculture export destinations outside the region. It is likely that South Asian countries having similar climatic conditions and resource endowments, produce similar agriculture products, trade more with countries outside the region such as Europe, America producing different agriculture products.

Country pairs with common language have advantages for total trade in world but it does not significantly influence on trade intensity in South Asian region. The coefficient indicates that country pairs which share common language have $0.64 \%$ higher trade intensities than the country pairs with different language in world total trade. Having strong colonial ties between two countries also have significant trade advantages as the coefficients are positive in sign in all three estimations. Being under same colonial rule, countries have $0.67 \%, 0.77 \%$ and $3.11 \%$ higher trade intensities in world total trade, South Asian total trade and South Asian agriculture trade respectively. That indicates trade under strong colonial ties brings more positive effects on agriculture trade linkage between two countries.

If both countries are WTO members those country pairs have higher trade intensities by $1.71 \%$ and $2.68 \%$ respectively for world and South Asian total trade. It indicates that WTO membership is important for South Asia countries to build-up strong trade relationships. However, it does not have significant influence on agriculture trade intensity.

The coefficient of bilateral trade agreements is positive in sign in all three models indicating $0.63 \%, 0.80 \%$ and $1.51 \%$ increase in trade intensities in the world, South Asia for total products and agriculture sector in South Asia respectively. Accordingly bilateral trade agreements in South Asian region bring more positive influences on agriculture trade.

Regional trade agreements are significant determinants of trade intensity in both world and South Asia for total trade, but not in agriculture trade. The coefficient is positive in sign and it implies countries being a party to regional trade agreements increase trade intensities by $0.37 \%$ and $1.12 \%$ 
respectively in world and South Asia. Even though regional trade agreements are important to build-up strong trade relationship in terms of total trade, they have not helped in improving agriculture trade intensities in the region. South Asian Countries have left agriculture out of list of liberalized commodities under South Asian Free Trade Agreement. Even under WTO agriculture has received some exceptions. But bilateral trade agreements such as Pakistan-Sri Lanka, Indo-Lanka are included agriculture as its major concern. This could be the reason for significance in bilateral trade agreements in agriculture trade intensity in South Asia.

The significant positive coefficient for diversification index in all three estimates indicates 0.1 unit increase in diversification index increases trade intensity in world, South Asia and South Asian agriculture sector by $0.32 \%$, $0.57 \%$ and $1.07 \%$ respectively. Accordingly, diversification of export market build higher trade relationships among South Asian countries in contrast to world and it is one of the key determinants in agriculture trade in South Asia.

\section{Concluding Remarks}

Agriculture trade intensities in South Asia indicate that countries in the region have higher trade exchange in contrast to its total product trade. India, Nepal and Sri Lanka show higher agriculture trade ties with each South Asian member countries and the strongest agricultural trade relationships prevails between Pakistan and Afghanistan. India has intense trade relationships for agricultural commodities with all the countries in the region. Though certain countries are better natural trading partners for agricultural products in the region, trade between those countries are nonexistent. Thus there is a room for future trade policy interventions to build intra regional trade partnerships in South Asia.

Among conventional gravity variables, GDP of exporter country, population of exporter and importer countries, distance and colonial ties are the key determinants of agriculture trade in the region. GDP of importer country is a determinant of total product trade intensity in both world and South Asia but it is not significant in agriculture trade. Common language is a determinant of world total trade intensities but not influencing factor for trade in South Asia. Even though being WTO members, and having regional trade agreements have trade advantages for total product trade it is not effective in agriculture trade in South Asia. Bilateral trade agreements significantly influence on trade between countries and it is more important determinant in agriculture trade. Export market diversification is a significant determinant of trade intensity and it's a more influencing factor in agriculture trade in South Asia. It can be concluded that bilateral trade agreements and 
export market diversification are the potential trade policy areas for interventions to build trade relationships among South Asian countries to promote intra regional agriculture trade.

\section{Acknowledgement}

The author gratefully acknowledge the financial assistance provided by AsiaPacific Research and Training Network on Trade (ARTNeT) to carry out this study and wish to express her gratitude to anonymous reviewers for constructive comments. The study was carried out while working at the Department of Agricultural Economics and Business Management, Faculty of Agriculture, University of Peradeniya.

\section{References}

Anderson, J.E. (2010). The Gravity Model. National Bureau of Economic Research, Cambridge. Working Paper No16576.

Baier, S.L. and J.H. Bergstrand (2007). Do Free Trade Agreements Actually Increase Members' International Trade. Journal of International Economics, 71: 72-95.

Baldwin, R. and D. Taglioni (2006).Gravity for Dummies and Dummies for Gravity Equations. National Bureau of Economic Research, Cambridge. Working paper No 12516.

Bano, S., Y. Takahashi and F. Scrimgeour (2013). ASEAN - New Zealand Trade Relations and Trade Potentials: Evidence and Analysis. Journal of Economic Integration, 28(1): 144-182.

Batra, A. (2007). ASEAN Economic Integration: ASEAN+3+1 or ASEAN+1? ASEAN Economic Bulletin, 24(2): 181-204.

Bergstand, J.H. (1990). The Heckscher-Ohlin-Samuelson Model: The Linder Hypothesis and Determinants of Bilateral Intra Industrial Trade. The Economic Journal, 100(403): 1216-1229.

Brooks, D.H. and C. Hua (2009). Asian Trade and Global Linkages. Asian Development Reviews, 26(1): 103-128.

Carney, M.K. (1973). Agriculture Trade Intensity: The European Market and the U.S. American Journal of Agricultural Economics, 55(4): 637640 . 
Emerging Lessons for Export Diversification (2009). The World Bank, Washington, D.C.

Fobes, K.J. and M.D. Chinn (2004). A Decomposition of Global Linkages in Financial Markets over Time. The Reviews of Economics and Statistics, 86(3): 705-722.

Hapsari, I.M. and C. Mangunsong (2006). Determinants of AFTA Member's Trade Flow and Potentials for Trade Diversification. Asia-Pacific Research and Training Network on Trade Working Paper Series, No 21.

Jafari Y., M.A. Ismail and M.S. Kouhestani (2011).Determinants of Trade Flow among D8 Countries: Evidence from the Gravity Model. Journal of Economic Cooperation and Development, 32(3): 21-38.

Ng, F. and A. Yeats (2003). Major Trade Trends in East Asia. World Bank Policy Research Working Paper 3084.

Reza, S. (1982). Trade Intensities of Bangladesh with South Asia and ASEAN. The Bangladesh Development Studies, 10(4): 97-112.

Rosa, A.,D., Govindan, K. Agriculture, Trade and Regionalism in South Asia. International food policy research institute. Brief 46, June 1997.

Shin, K.(2008). Global and Regional Shock: Challenges to Asian Economics. ADB Institute Working Paper.No120.

Srivastava, R.K. and R.T. Green (1986). Determinants of Bilateral Trade Flows. The Journal of Business, 59(4): 623-640.

ST/ESCAP,(2009). Trade Statistics in policy making. United Nations Economic and Social Commission for Asia and the Pacific, Bangkok, Thailand.

Zhang, J. and A.V. Witteloostuijn (2004). Economic Openness and Trade Linkages of China: An Empirical Study of the Determinants of Chinese Trade Intensities from 1993 to $1999 . \quad$ Review of World Economics, 140(2): 254-281.

Zarzoso, I.M. and F.M. Lehman (2003). Augmented Gravity Model: Empirical Applications to MERCOSUR-EUROPEAN UNION TradeFlows. Journal of Applied Economics, 2: 291-316. 